\title{
Absorption properties of chromophoric dissolved organic matter (CDOM) in the East China Sea and the waters off eastern Taiwan
}

\author{
Fengxia Zhou ${ }^{\mathrm{a}, \mathrm{b}}$, Xuelu Gao ${ }^{\mathrm{a}, \mathrm{f}, *}$, Jinming Song ${ }^{\mathrm{c}, \mathrm{e}, \mathrm{f}}$, Chen-Tung Arthur Chen ${ }^{\mathrm{d}}$, Huamao Yuan ${ }^{\mathrm{c}, \mathrm{e}, \mathrm{f}}$, \\ Qianguo Xing ${ }^{\mathrm{a}}$ \\ ${ }^{\text {a }}$ CAS Key Laboratory of Coastal Environmental Processes and Ecological Remediation, Yantai Institute of Coastal Zone Research, Chinese Academy of Sciences, Yantai, \\ Shandong 264003, China \\ ${ }^{\mathrm{b}}$ Guangdong Province Key Laboratory for Coastal Ocean Variation and Disaster Prediction Technologies, Guangdong Ocean University, Zhanjiang, Guangdong 524088, \\ China \\ ${ }^{c}$ CAS Key Laboratory of Marine Ecology and Environmental Sciences, Institute of Oceanology, Chinese Academy of Sciences, Qingdao, Shandong 266071, China \\ d Department of Oceanography, National Sun Yat-sen University, Kaohsiung 80424, Taiwan \\ e Function Laboratory of Marine Ecology and Environmental Sciences, Qingdao National Laboratory of Marine Science and Technology, Qingdao, Shandong 266237, \\ China \\ ${ }^{\mathrm{f}}$ University of Chinese Academy of Sciences, Beijing 100049, China
}

\section{A R T I C L E I N F O}

\section{Keywords:}

Colored dissolved organic matter

Optical properties

Biogeochemical cycling

Water mass tracing

East China Sea

Marginal Sea

\begin{abstract}
A B S T R A C T
The absorption properties of chromophoric dissolved organic matter (CDOM) in the East China Sea (ECS) and the waters off eastern Taiwan (WET) were studied during May 2014. CDOM absorption coefficient $\left(a_{280}\right)$ and spectral slope $\left(S_{275-295}\right)$ revealed considerable spatial variations. In the ECS, the values of $a_{280}$ and $S_{275-295}$ presented a reverse distribution pattern. In the WET, $a_{280}$ values were generally low while $S_{275-295}$ values were generally high. Vertical distributions of $a_{280}$ and $S_{275-295}$ also varied in different regions. Terrestrial input, phytoplankton production, sediment release or photobleaching may be responsible for the dynamics of CDOM. Relationships among CDOM related parameters could partly support this conclusion. $a_{280}$ were also used to trace different water masses and the result showed that the influence of Changjiang Diluted Water could reach the outer shelf of the northern ECS, and that the Kuroshio Current had a strong influence on the middle shelf of the southern ECS.
\end{abstract}

\section{Introduction}

Chromophoric dissolved organic matter (CDOM), also known as colored dissolved organic matter, is the colored fraction of the organic compounds dissolved in the water. It is a heterogeneous mixture of organic compounds and ubiquitous in all natural waters (Guéguen and Kowalcyuk, 2013; Guéguen et al., 2014; Wang et al., 2014). CDOM has the property of absorbing light in a long spectrum and a fraction of it may be fluorescing when excited by light in the ultraviolet (UV) and blue region (D'Sa et al., 2014; Organelli et al., 2014). The absorption spectrum is log-linearized and decreases exponentially with increasing wavelengths, which are typical features of CDOM absorption spectra (Yang and Hur, 2014). The absorbance at certain wavelength can represent the CDOM concentration (Yang, 2012; Liu et al., 2014a; Yu et al., 2016) and the spectral slope of the absorbance spectrum can represent the sources, ages, or the compositions of CDOM (Helms et al.,
2008; Organelli et al., 2014). CDOM absorption properties may have close relationships with salinity, chlorophyll $a$ (Chl $a$ ), or other parameters, which could help in identifying water masses, quantifying certain parameters, determining origins and so on (Lei et al., 2012; Matsuoka et al., 2015; Yang et al., 2016).

CDOM plays an important role in the biogeochemistry of natural waters. The absorption of UV radiation by CDOM can protect organisms from UV damage, while the absorption of visible light by CDOM may reduce the amount and quality of the photosynthetically active radiation available to phytoplankton, thus decreasing primary productivity (Bidigare et al., 1993; Guéguen et al., 2005). In areas where CDOM concentrations are high, such as coastal regions, much of the ocean color signature in the blue part of the spectrum is due to CDOM absorbance, not Chl $a$ absorbance (Coble et al., 1998 and references therein). High concentrations of CDOM can reduce the photic depth, resulting in light limitation for deeper waters (Laurion et al., 2000;

\footnotetext{
* Corresponding author at: CAS Key Laboratory of Coastal Environmental Processes and Ecological Remediation, Yantai Institute of Coastal Zone Research, Chinese Academy of Sciences, Yantai, Shandong 264003, China.

E-mail address: xlgao@yic.ac.cn (X. Gao).
} 
Stedmon et al., 2011). Photo-degradation and microbial degradation of $\mathrm{CDOM}$ can result in the emission of the greenhouse gases such as $\mathrm{CO}_{2}$ and $\mathrm{CH}_{4}$ (Miller and Zepp, 1995; Zhang and Xie, 2015), accelerating global warming (Tranvik et al., 2009; Zhang et al., 2010a). Reactive oxygen species can also be produced photochemically from the CDOM, which may harm aquatic organisms (Blough and Zepp, 1995). Therefore, it is important to study the dynamics of CDOM in seawater.

China, especially its east coastal region, has been experiencing rapid economic development in recent decades. As a consequence, the coastal regions of China have been undergoing obvious environmental degradation, such as eutrophication, frequent occurrence of harmful algal blooms, elevated productivity, seasonal hypoxia in bottom water, trace metal pollution and so on (Zhou et al., 2008; Gao and Chen, 2012; Pan and Wang, 2012; Yu et al., 2013; Gao et al., 2015a, 2015b; Liu et al., 2015; Xing et al., 2015). The East China Sea (ECS) is a typical epicontinental sea which is under the influence of heavy urbanization and industrialization (Gao et al., 2010; Zhang et al., 2010b; Su et al., 2015). Many industrial and urban centers are located in eastern China along the ECS coast. In recent decades, high loads of industrial effluents and domestic sewage have been discharged into the coastal regions of the ECS (Gao et al., 2010; Zhang et al., 2010b; Su et al., 2015), which could affect the CDOM concentration, composition, and reactivity (Sun et al., 2014). The waters off eastern Taiwan (WET) are deep, and the main stream of the Kuroshio flows northwards through this area and then enters the ECS after crossing the I-Lan Ridge (Chen et al., 1995; Chen, 1996; Chen and Wang, 2006), which may have profound effect on the properties of CDOM in the ECS.

Some attention has been paid to the biogeochemistry of CDOM in the ECS, and a general understanding of its basic geochemistry has been achieved. Gong (2004) investigated the spatial distributions of CDOM in the surface waters of the ECS and found that concentrations of CDOM decreased from the inner shelf near the coast toward the offshore region, indicating strong influence of terrestrial inputs. Liu et al. (2014b) investigated the absorption properties of CDOM in the surface water of the Changjiang Estuary and its adjacent regions and found a northwest to southeast decreasing trend of CDOM concentrations. Besides, they found that the CDOM absorption in the surface water of the Changjiang Estuary sharply increased during phytoplankton blooms and it covaried with dissolved organic carbon to some extent (Liu et al., 2014b). Sun et al. (2014) studied the source and spatial dynamics of CDOM in the surface water of the Changjiang Estuary. This study showed that the distribution of CDOM was dominated by allochthonous input, conservative mixing, and phase transfer (Sun et al., 2014). In addition, $\mathrm{CDOM}$ in the surface water, bottom water and pore water in the Changjiang Estuary was studied by Wang et al. (2014), and their results indicated that concentrations of $\mathrm{CDOM}$ in the pore water were much higher than those in the surface and bottom water. The release of CDOM from sediments and the loss of CDOM in surface water caused by photobleaching were responsible for that phenomenon (Wang et al., 2014). Yu et al. (2016) developed an empirical model to estimate dissolved organic carbon concentration based on the absorption properties of CDOM in the Changjiang Estuary. Little information could be obtained concerning the properties of CDOM in the WET, which may have profound influence on the biogeochemistry of CDOM in the ECS. Although the above-mentioned endeavors made by researchers have gained some general understanding of the CDOM properties in the ECS, the knowledge of the CDOM characteristics and their relationships with hydrography were still limited. Besides, CDOM absorption properties have often been used to trace water masses in different sea areas around the world (Granskog et al., 2007; Stedmon et al., 2010; Matsuoka et al., 2012), while similar research is rare in the ECS and the WET especially involving both of them at the same time as related parts.

Therefore, a study on the absorption properties of CDOM was carried out in the ECS shelf, extending approximately from the east of Zhoushan Archipelago to the north of Taiwan Strait, and the WET in the Kuroshio Current path (Fig. 1), attempting to investigate the distribution patterns of CDOM in both surface waters and vertical profiles, discuss the relationships among CDOM related parameters, and trace water masses based on CDOM properties. This study involved a larger water system than those of previous studies, which favored to the further analysis of CDOM absorption properties in complex water masses.

\section{Materials and methods}

\subsection{Study area and sampling}

The study area includes most parts of the ECS shelf with water depths between $\sim 30-110 \mathrm{~m}$ and the WET with water depths between $\sim 600-5000 \mathrm{~m}$ (Fig. 1). The ECS is strongly influenced by many rivers, in which the Changjiang topped the list. The Changjiang is the third largest river in the world with a large quantity of freshwater discharge $\left(9.24 \times 10^{11} \mathrm{~m}^{3} \mathrm{a}^{-1}\right)$ (Bai et al., 2013). Compared to the ECS, the WET is influenced relatively less by anthropogenic activities due to relatively less pollution in the eastern Taiwan (Zhou, 1994; Ling, 1999). The hydrographic properties of the studied region were markedly influenced by a circulation system, including the Changjiang Diluted Water (CDW), the Zhejiang-Fujian Coastal Current (ZFCC), the Taiwan Warm Current (TWC), and the Kuroshio Current (KC) (Liu et al., 2008; Zhu et al., 2011; Fig. 1).

Water samples in this study were collected with Niskin bottles, which were mounted on a rosette together with a conductivity-temperature-depth (CTD) profiler, during a cruise from May 22 to June 11 in2014on board R/V Science I (Fig. 1). There were 48 sampling stations located at the ECS and 7 sampling stations at the WET (Fig. 1). Among these sampling stations, 6 cross-sections were sampled in vertical profile (DH2, DH4, DH6, DH9, TW1 and TW2; Fig. 1) to reflect the vertical properties of CDOM, with 3-13 different depths sampled at one station according to the water depth. Only the surface waters were collected at the other sampling stations from the depth of $\sim 3 \mathrm{~m}$. Hydrographic data were collected by the CTD which recorded depth, temperature and salinity. Water samples were analyzed for CDOM at depths between 3 and $2000 \mathrm{~m}$ and Chl $a$ at depths between 3 and $200 \mathrm{~m}$.

\subsection{Analytical methods}

Water samples for $\mathrm{CDOM}$ analysis were filtered through precombusted $\left(4 \mathrm{~h}\right.$ at $450{ }^{\circ} \mathrm{C}$ ) $0.7 \mu \mathrm{m} \mathrm{GF} / \mathrm{F}$ filters to remove suspended solids and plankton directly after collection (Lin et al., 2016). The filtrate was then collected into glass bottles that had been pre-combusted at $450{ }^{\circ} \mathrm{C}$ for $4 \mathrm{~h}$. Until warmed to room temperature, the filtrated water samples underwent absorption analysis within $6 \mathrm{~h}$ of collection.

Based on Milli-Q water blanks, samples' absorption spectra were obtained between 240 and $800 \mathrm{~nm}$ at $1 \mathrm{~nm}$ intervals using a UV-Vis spectrophotometer (T6, Persee, China) equipped with $10 \mathrm{~cm}$ quartz cells. The average value of sample absorbance between 700 and $800 \mathrm{~nm}$ was subtracted from the spectrum to correct for offsets due to instrument baseline drift (Yang, 2012). The cuvette was rinsed with Milli-Q water between individual scans to minimize cross contamination. Absorbance data were converted to absorption coefficient $\left(a_{\lambda}: \mathrm{m}^{-1}\right)$ according to the equation (Hu et al., 2002):

$a_{\lambda}=2.303 A(\lambda) / l$

where $l$ is the path-length of the optical cell in meters, and A( $\lambda)$ is the absorbance at certain wavelength. In this study, absorption coefficient at wavelength of $280 \mathrm{~nm}\left(a_{280}\right)$ was used as an estimate for CDOM concentration (Lin et al., 2012; Yang, 2012). 20\% of the water samples were scanned in duplicate and the standard deviations on duplicate $a_{280}$ measurements for these selected samples were less than 3\%. Absorption coefficients at other wavelengths (325, 350, 355 and $443 \mathrm{~nm})$ were also calculated to compare with related studies. The spectral slope for the interval of 275-295 $\mathrm{nm}\left(S_{275-295}\right)$, which can be used as an indicator of 


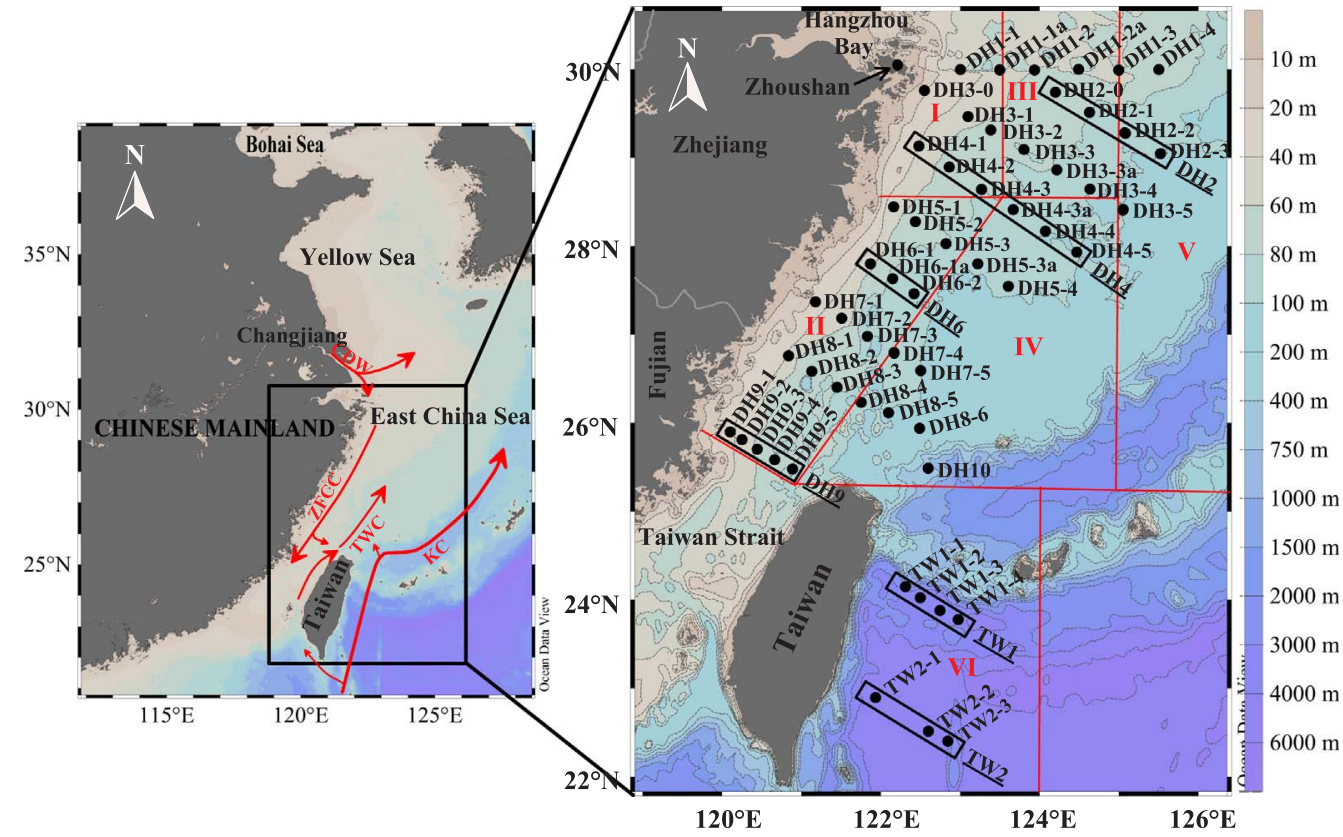

Fig. 1. Locations of sampling stations in the East China Sea and the waters off eastern Taiwan. The cross-sections showed in boxes were sampled in vertical profile. Other crosssections were sampled at surface water. The sampling stations were classified into six categories by the red lines based on the geographical regions where they located. The sampling stations in the East China Sea shelf were classified into five categories according to the study of Fang et al. (2007) and the rest were classified as the sixth category. The name of each category was: (I) estuary, (II) inner shelf, (III) northern middle shelf, (IV) southern middle shelf, (V) outer shelf, and (VI) waters off eastern Taiwan, respectively. The major currents in the study area are schematically shown. CDW, ZFCC, TWC and KC represent the Changjiang Diluted Water, the Zhejiang-Fujian Coastal Current, the Taiwan Warm Current and the Kuroshio Current, respectively. molecular weight (Helms et al., 2008) or as a tracer of photochemical degradation processes (Organelli et al., 2014), was calculated according to Helms et al. (2008). The standard deviations on duplicate $S_{275-295}$ measurements for the selected samples were less than $0.2 \%$.

Water samples for Chl $a$ analysis were immediately filtered through cellulose acetate membrane on board and the filters were stored at $-20{ }^{\circ} \mathrm{C}$ until analysis in laboratory. The Chl $a$ retained on the filters was extracted with $90 \%$ acetone and determined spectrofluorometrically (Strickland and Parsons, 1972; Gong et al., 1993, 1995) with a fluorometer (Hitachi F-4600, Japan).

\section{Results and discussion}

\subsection{General hydrography}

Fig. 2 illustrates the temperature, salinity and Chl $a$ variations in surface waters of the ECS and the WET. Surface water $(\sim 3 \mathrm{~m})$ temperature increased seaward from $\sim 18{ }^{\circ} \mathrm{C}$ in the inshore regions to $\sim$ $26^{\circ} \mathrm{C}$ in the offshore regions of the ECS while salinity increased seaward from $\sim 26$ to $\sim 34$ across the same area (Fig. $2 \mathrm{a}$ and b). In the WET, surface salinity and temperature both exhibited rather narrow ranges of variation (salinity: $34.3-34.7$; temperature: $26.4-27.9^{\circ} \mathrm{C}$ ) (Fig. $2 \mathrm{a}$ and b). Concentrations of Chl $a$ presented a seaward decreasing trend in the surface water of the ECS, ranging from 0.024 to $8.31 \mu \mathrm{g} \mathrm{L}-1$ (Fig. 2c).
The range for $\mathrm{Chl} a$ in the surface water of the WET was0.033-1.31 $\mu \mathrm{g} \mathrm{L}^{-1}$, which was relatively low compared with corresponding value in the inshore regions of the ECS (Fig. 2c).

Temperatures generally decreased from surface waters to bottom waters in both of the ECS and the WET (Fig. 3). In the ECS, temperatures of bottom waters (average depth of $78 \mathrm{~m}$ ) were $\sim 18{ }^{\circ} \mathrm{C}$, while in the WET, temperatures of deep waters $(\sim 2000 \mathrm{~m})$ decreased to $\sim 2{ }^{\circ} \mathrm{C}$ (Fig. 3). Salinity in the ECS stratified in the inshore regions but became relatively well mixed farther seaward, while in the WET, salinity was relatively vertically stable (Fig. 3). At some stations in the ECS, the concentrations of $\mathrm{Chl} a$ had maximum values in the subsurface water and the depths with the subsurface $\mathrm{Chl} a$ maxima increased seaward (Fig. 3). The position with the subsurface maximum values of Chl $a$ in the WET was not obvious compared with that of the ECS (Fig. 3).

Temperature and salinity can be used to identify different water masses (Chen et al., 1995; Chen and Wang, 2006). The CDW and ZFCC are low in salinity and temperature (Chen et al., 1995). The TWC has relatively high salinity and temperature compared with those of the CDW and the ZFCC (Chen et al., 1995). The surface water of the KC is characterized by the highest salinity and temperature among the water masses that dominated the ECS shelf (Chen et al., 1995). The low temperature and salinity waters adjacent to the ECS coast could reflect the northward retreating ZFCC that had previously been transported southwestward during the northeastern monsoon (Fig. 2a and b; Chen

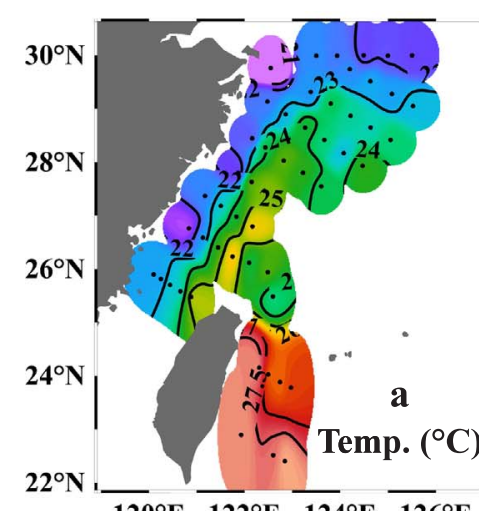

$\overline{120}^{\circ} \mathrm{E} \overline{122}^{\circ} \mathrm{E} \overline{124}^{\circ} \mathrm{E} \overline{126}^{\circ} \mathrm{E}$
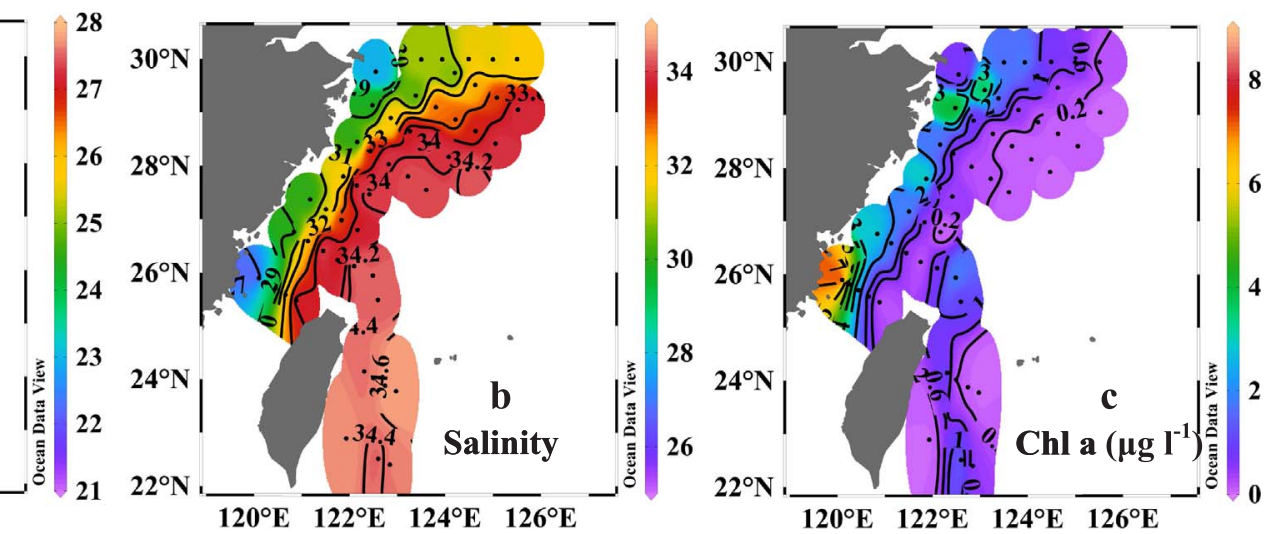

Fig. 2. Spatial distributions of temperature, salinity and Chl $a$ in surface water. 

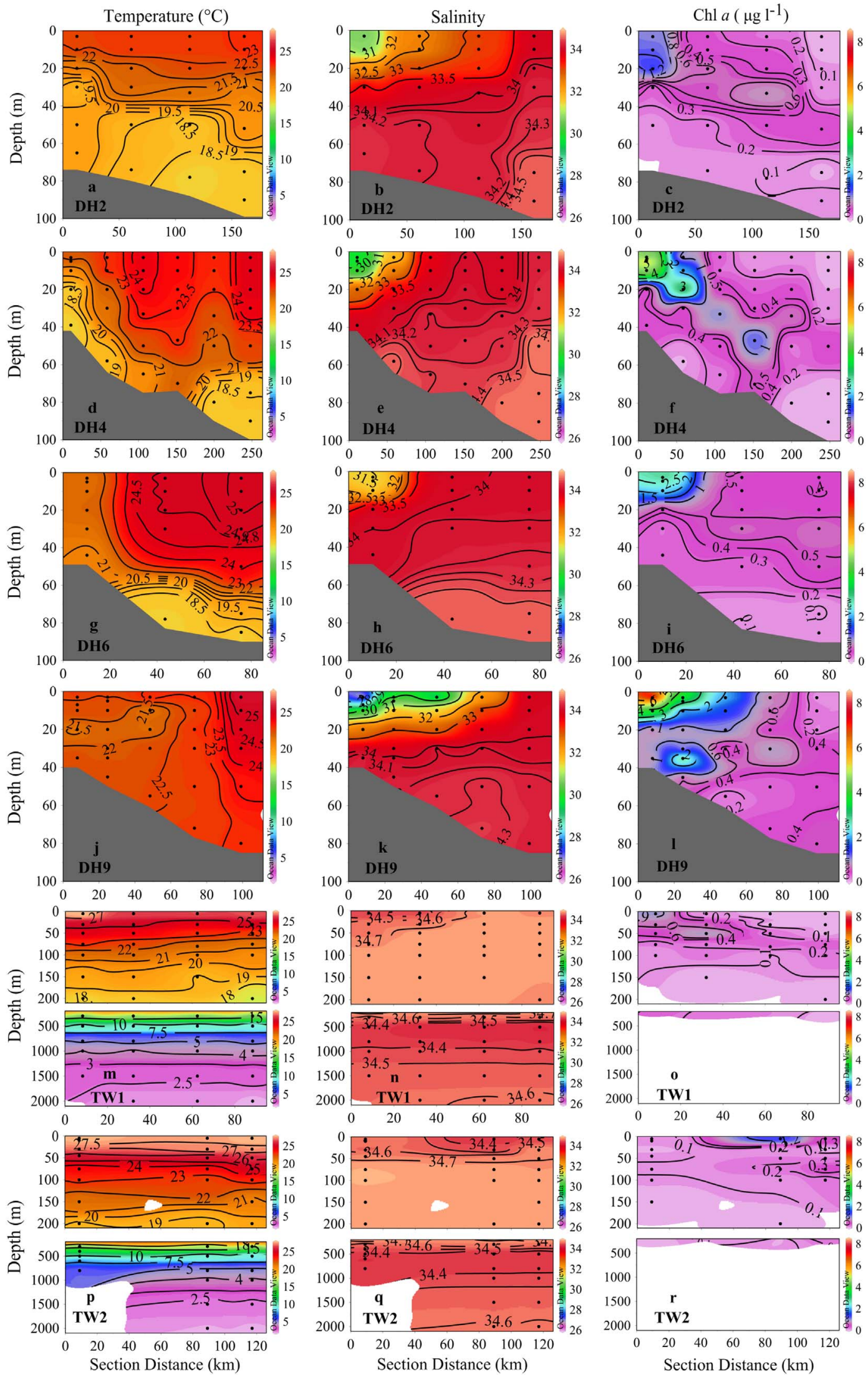

Fig. 3. Vertical distributions of temperature, salinity and Chl $a$. 


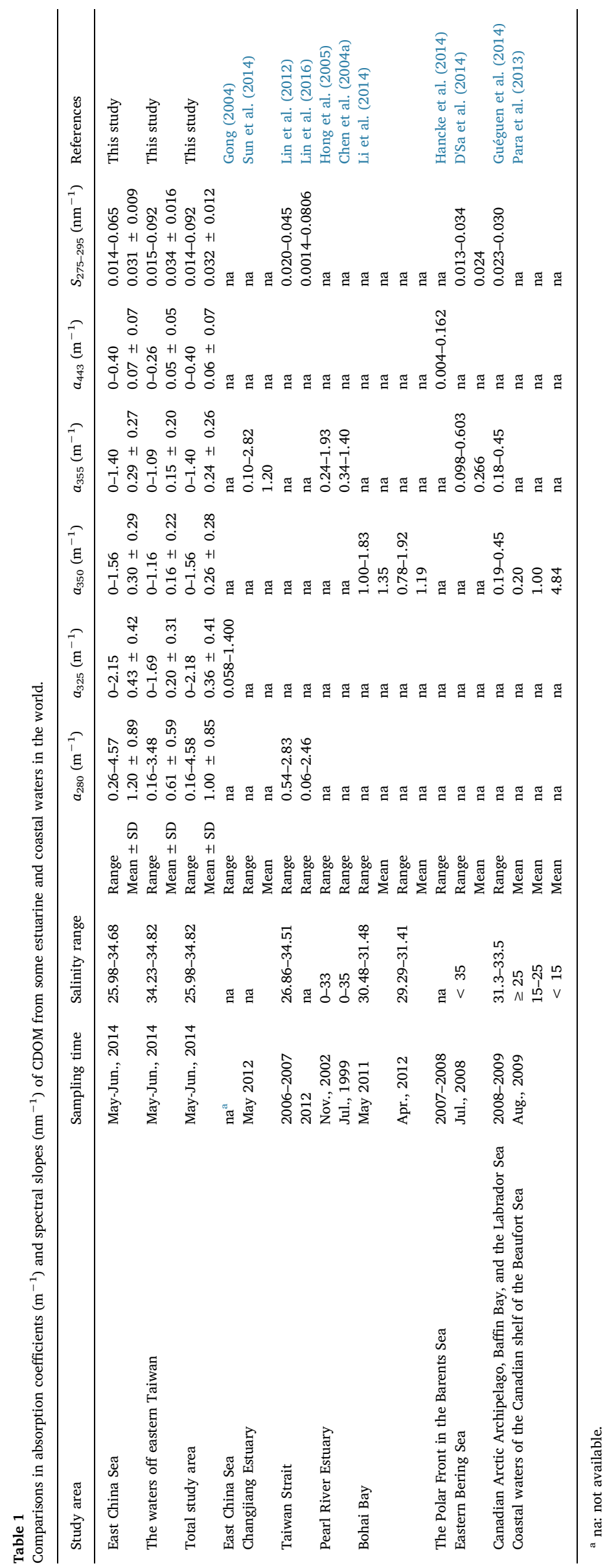


et al., 2003; Naik and Chen, 2008). The low temperature and salinity that nearly extended to the outer shelf of the northern ECS could reflect the influence of the CDW (Fig. 2a and b). The relatively high temperature and salinity off northwestern Taiwan could reflect the path of the TWC (Fig. 2a and b; Chen et al., 1995). The high temperature and salinity off northeastern Taiwan could reflect the flow pattern of the KC (Fig. 2a and b; Chen et al., 1995).

\subsection{Absorption properties of CDOM}

\subsubsection{Spatial distributions of CDOM absorption coefficients}

Absorption coefficients at the wavelengths of 280, 325, 350, 355 and $443 \mathrm{~nm}\left(a_{280}, a_{325}, a_{350}, a_{355}\right.$ and $\left.a_{443}\right)$ were used in previous studies to represent CDOM concentrations (Gong, 2004; Hong et al., 2005; Lin et al., 2012, 2016; Hancke et al., 2014; Li et al., 2014). The values of $a_{280}, a_{325}, a_{350}, a_{355}$ and $a_{443}$ obtained in this study were significantly correlated (ECS: $\mathrm{R}^{2}>0.87 ; P<0.001, \mathrm{n}=183$; WET: $\mathrm{R}^{2}>0.88, P<0.001, \mathrm{n}=89$ ), supporting $a_{280}$ as an indicator of CDOM concentration in the ECSS. Therefore, only $a_{280}$ was used for further analysis in this study. $a_{325}, a_{350}, a_{355}$ and $a_{443}$ were also shown in Table 1 to facilitate comparison with previous data. The range of $a_{280}$ and $a_{325}$ in the ECS in this study was comparable to those previously reported for the ECS (Gong, 2004) and the Taiwan Strait (Lin et al., 2012, 2016). The values of $a_{350}$ and $a_{355}$ observed in the ECS and the WET in this study were generally lower than those reported for the Changjiang Estuary (Sun et al., 2014), the Pearl River Estuary (Chen et al., 2004a; Hong et al., 2005), and the Bohai Bay (Li et al., 2014) (Table 1). The $a_{350}$ values obtained in this study were comparable with those reported in Para et al. (2013) for surface coastal waters in the North East Sector of the Canadian Beaufort Sea shelf where salinity was higher than 25. The values of $a_{355}$ and $a_{443}$ in the ECS in this study were also comparable with those of the Eastern Bering Sea (D'Sa et al., 2014) and the polar front in the Barents Sea (Hancke et al., 2014), respectively.

In the whole water systems of the study area, the values of $a_{280}$ ranged from 0.16 to $4.58 \mathrm{~m}^{-1}$, with an average value of $1.00 \pm 0.85 \mathrm{~m}^{-1}$ (Table 1 ). In the ECS, the values of $a_{280}$ ranged from 0.26 to $4.58 \mathrm{~m}^{-1}$, with an average value of $1.20 \pm 0.89 \mathrm{~m}^{-1}$ (Table 1 ). In the WET, the values of $a_{280}$ ranged from 0.16 to $3.48 \mathrm{~m}^{-1}$, with an average value of $0.66 \pm 0.59 \mathrm{~m}^{-1}$ (Table 1 ). The average value of $a_{280}$ in the ECS was obviously higher than that of the WET. The distribution of $a_{280}$ in the surface water of the ECS differed substantively from that in the WET, with relatively high $a_{280}$ values in the inshore regions of the ECS and relatively low $a_{280}$ values in the offshore regions of the ECS, while in the WET, the values of $a_{280}$ were low in the whole region and did not present obvious seaward decreasing trend (Fig. 4a). Similar to that of the condition in the inner shelf region around the Kuskokwim
River (D'Sa et al., 2014), high CDOM waters in the inshore regions of the ECS were likely of terrestrial origin. Gong (2004) and Lei et al. (2012) reported the spatial distributions of CDOM absorption coefficients in the ECS in summer with the high-value part in northwestern region and the relatively low patch in offshore waters, which was comparable in shape to that of this work.

The vertical spatial variability of $a_{280}$ presented some different characteristics at different sampling stations (Fig. 5a-f). In the inshore regions of the ECS where water column was stratified (Fig. 1; Fig. 3), CDOM had relatively high concentrations in surface water and generally decreased with depth (Fig. 4a and b). At some stations in the inshore or offshore regions of the ECS, CDOM concentrations had relatively high values in subsurface or bottom waters (Fig. 5a-d). In the offshore regions where the water column was relatively well mixed (Fig. 3), the vertical distribution of CDOM was relatively homogenous with slight elevations at the subsurface or bottom waters (Fig. 5a-d). Similar phenomena were also observed in other estuarine-influenced marine regions (Gardner et al., 2005; Del Castillo and Miller, 2011; Yu et al., 2016). In the WET, the subsurface maximum $a_{280}$ values occurred at $\sim 300 \mathrm{~m}$ depth (Fig. 5e and f). Besides, the values of $a_{280}$ in surface and deep waters in the WET were generally low compared with those in the ECS (Fig. 5a-f). The diffusion of terrestrial water with high concentrations of CDOM was responsible for the decreasing trend of CDOM concentrations with the increase of depth in the inshore regions of the ECS. In situ production by phytoplankton and diffusion from underlying sediments should be responsible for the CDOM concentration increase in the subsurface and the bottom waters, respectively (Boss et al., 2001; Xie et al., 2012a; D'Sa et al., 2014). Bleached by solar radiation (i.e., photobleaching) in surface water, CDOM absorption coefficients degraded (Vodacek et al., 1997; Nelson et al., 1998; Swan et al., 2012), which could explain the relatively low concentrations of CDOM in surface water of the WET.

\subsubsection{Spatial distributions of CDOM spectral slope}

Spectral slope, another absorption spectral index, can provide further insights into the general characteristics of CDOM (e.g. source and diagenesis) than absorption values (Carder et al., 1989; Helms et al., 2008; Fichot and Benner, 2011; Matsuoka et al., 2012; Fichot et al., 2013; Guéguen et al., 2014). Steeper slopes signify lower molecular weight material and vice-versa (Blough and Del Vecchio, 2002; Helms et al., 2008). High values of spectral slopes are often used to diagnose the past history of photobleaching (Green and Blough, 1994). Besides, they can also be used as an indicator of newly produced CDOM (Nelson et al., 2004). Low values of spectral slopes have been linked with terrestrial-origin CDOM (Green and Blough, 1994; Del Vecchio and Subramaniam, 2004; Granskog et al., 2007).

We used spectral slope from 275 to $295 \mathrm{~nm}\left(S_{275-295}\right)$ that were also
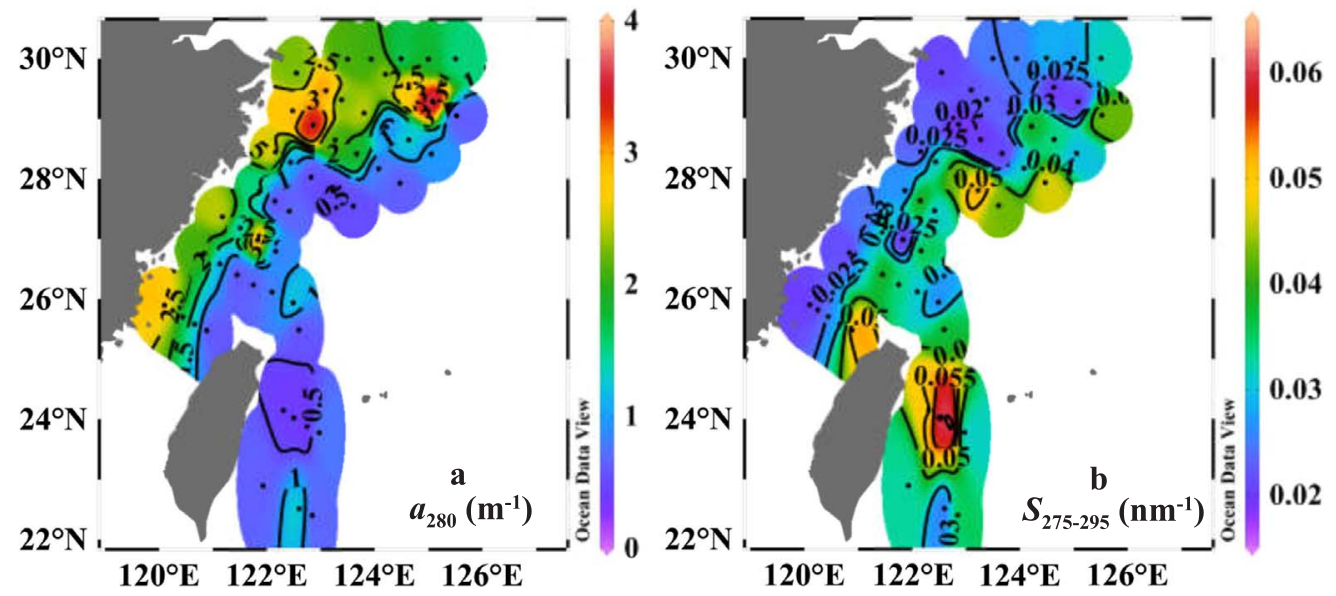

Fig. 4. Spatial distributions of $a_{280}$ and $S_{275-295}$ in surface water. 

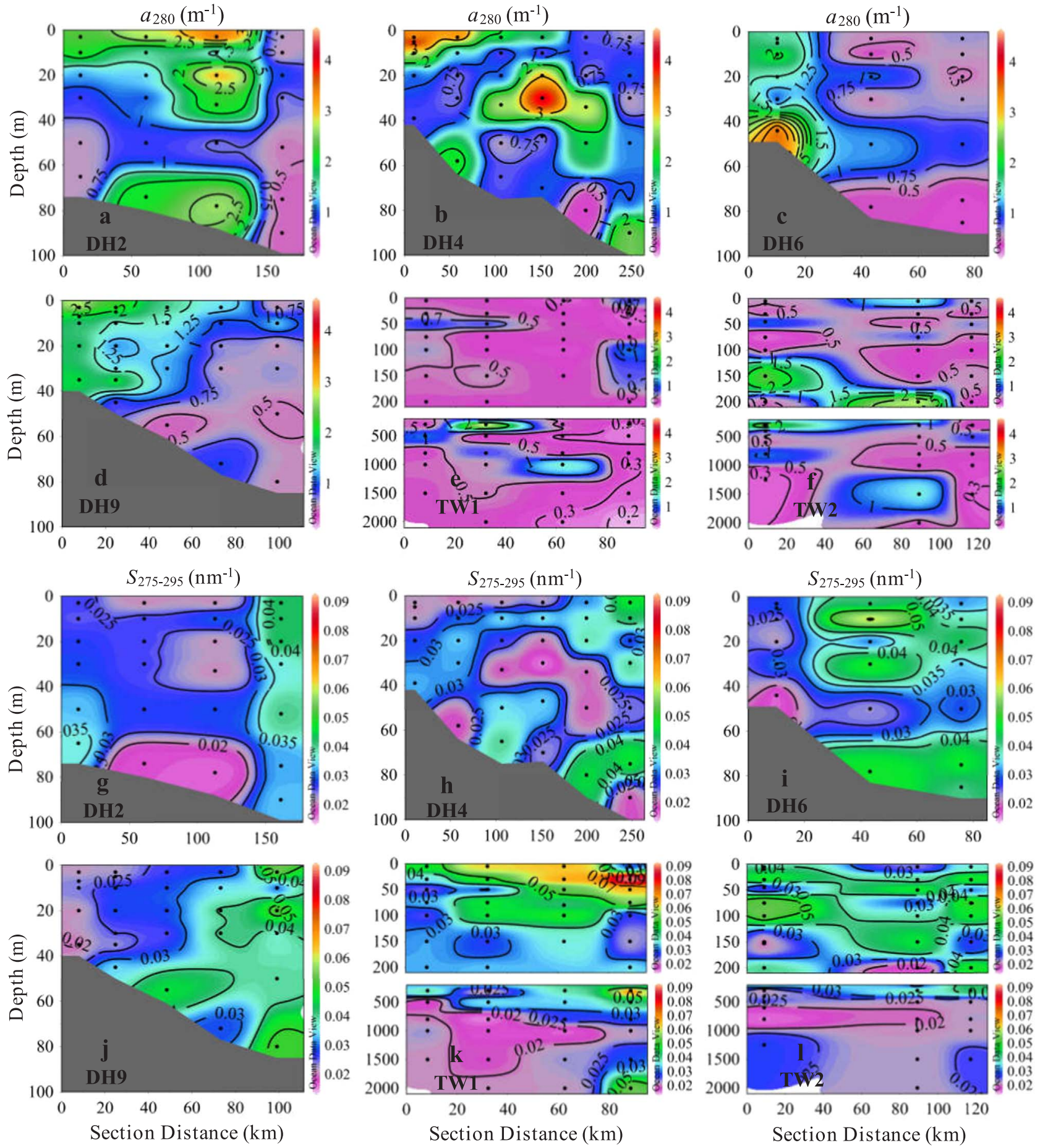

Fig. 5. Vertical distributions of $a_{280}$ and $S_{275-295}$

used in many other studies (Helms et al., 2008; Lin et al., 2012, 2016; Dainard and Guéguen, 2013; D'Sa et al., 2014; Guéguen et al., 2014) to study the characteristics of CDOM in this study. The values of $S_{275-295}$ obtained in this study were comparable to those reported for the Taiwan Strait (Lin et al., 2012, 2016), the Eastern Bering Sea (D'Sa et al., 2014), the Canadian Arctic Archipelago, the Baffin Bay, and the Labrador Sea (Guéguen et al., 2014) (Table 1).

In May 2014, the $S_{275-295}$ ranged from 0.014 to $0.092 \mathrm{~nm}^{-1}$ including both the ECS and the WET, with an average value of $0.032 \pm 0.012 \mathrm{~nm}^{-1}$ (Table 1). Values of $S_{275-295}$ in the ECS ranged from 0.014 to $0.065 \mathrm{~nm}^{-1}$, with an average value of $0.031 \pm 0.009 \mathrm{~nm}^{-1}$. Values of $S_{275-295}$ in the WET ranged from 0.015 to $0.092 \mathrm{~nm}^{-1}$, with an average value of $0.034 \pm 0.016 \mathrm{~nm}^{-1}$. Average value of $S_{275-295}$ in the WET was relatively higher compared with that of the ECS. Fig. $4 \mathrm{~b}$ shows the distribution of $S_{275-295}$ in surface water. The distribution of $S_{275-295}$ in surface water was in contrast to that of $a_{280}$, with relatively low values in the inshore regions of the ECS and relatively high values in the offshore regions of the ECS and the WET (Fig. 4b). This indicates that the surface water of the inshore regions of the ECS had relatively higher mean molecular weight of CDOM than the other parts of the study area, similar to the situation reported by D'Sa et al. (2014) in the eastern Bering Sea. The terrestrial input of high molecular weight CDOM contributed much to that phenomenon (Fig. 4; Fichot et al., 2013; D'Sa et al., 2014; Guéguen et al., 2014; Xu 
and Guo, 2017).

At some stations in the inshore area of the ECS, the values of $S_{275-295}$ generally increased with increasing depth, manifesting that the mean molecular weight of CDOM decreased with increasing depth (Fig. $5 g$ and $\mathrm{h}$ ), likely due to the vertical diffusion of terrestrial high molecular weight CDOM in the water column. The increasing trend of $S_{275-295}$ with the increase of depth was not found at stations DH6-1 and DH9-1 (Fig. 1; Fig. $5 \mathrm{i}$ and j). The release of high molecular weight CDOM from sediment may contribute to this phenomenon (Boss et al., 2001; D'Sa et al., 2014). In the offshore regions of the ECS where water was relatively well mixed (Fig. 3), values of $S_{275-295}$ were generally high in the whole water column (Fig. 3; Fig. $5 g$, i and j). The dominance of offshore water which had low molecular weight CDOM was likely responsible for that phenomenon. In the WET, values of $S_{275-295}$ were generally high at shallow waters and decreased to relatively constant values at deep waters (Fig. 5k and 1), manifesting that the molecular weight of CDOM in surface waters was relatively low (D'Sa et al., 2014). This vertical distribution could be explained by the strong photobleaching in shallow water, which could degrade CDOM constituents and yield high spectral slopes (Swan et al., 2012).

\subsection{CDOM properties as environmental indications and relationships among CDOM-related parameters}

As shown above, the study area had different CDOM characteristics in different regions. Based on Fang et al. (2007), the ECS shelf could be divided into five subregions, namely estuarine area, inner shelf area, northern middle shelf area, southern middle shelf area and outer shelf area, according to the sediment mass accumulation rate (Fang et al., 2007). To further examine the CDOM properties and their relationships with other parameters, all sampling stations in this study were divided into six categories. As shown in Fig. 1, in addition to the five categories of sampling stations in the ECS shelf referenced to the boundaries showed in Fang et al. (2007), the sampling stations in the WET was classified as the sixth category. According to the understanding of water masses in the study area (Fig. 1), it could be found that the sampling stations of category I is mainly influenced by the CDW, category II is mainly influenced by the ZFCC, category VI is mainly influenced by the $\mathrm{KC}$, category III may be influenced by the CDW and TWC, category IV may be influenced by the ZFCC, the TWC and the KC, and category V may be influenced by the $\mathrm{CDW}$ and the $\mathrm{KC}$.

\subsubsection{CDOM properties as environmental indications}

CDOM properties have often been used to trace water masses (Gong, 2004; Granskog et al., 2007; Lei et al., 2012; Lin et al., 2012; Matsuoka et al., 2012; Sasaki et al., 2014). Lei et al. (2012) reported that the low salinity plume in the ECS coincided with the region where high values of absorption coefficients dominated, indicating that the absorption coefficients of CDOM may be used to trace water masses. Gong (2004) studied the absorption coefficients in the surface water of the ECS and found that higher concentrations of CDOM were mostly contributed by river runoff while the offshore low concentrations of CDOM were strongly influenced by the Kuroshio waters. Although the previous studies had obtained some basic understanding of the relationship between the distributions of water masses and CDOM in the ECS, their quantitative linkages in a greater study area remain to be explored. Using our new data in the ECS and WET, the spatial characteristics of CDOM absorption properties coupling with water masses in different geographical regions of the study area are summarized below.

For the sampling stations in a certain category, the average value of a characteristic parameter could reflect the general feature of the water mass influencing these stations to some extent. The average values of $a_{280}$ of the sampling stations in categories I-VI were $1.78 \pm 1.17$, $1.14 \pm 0.77, \quad 1.30 \pm 0.70, \quad 0.89 \pm 0.78, \quad 1.28 \pm 1.03$ and $0.61 \pm 0.59 \mathrm{~m}^{-1}$, respectively, presenting a descending order of I $>$ III $>$ V $>$ II $>$ IV $>$ VI by regions (Table 2). From these average values, we could conclude that the CDW had the highest CDOM concentration, the KC had the lowest CDOM concentration, and the CDOM concentration of the ZFCC was relatively low compared with that of the CDW. The average CDOM concentrations of the sampling stations in categories III and V were close to those of the sampling stations in category I, indicating that the northern part of the study area was dominated by the CDW. The average CDOM concentration of the sampling stations in category IV was close to that of the sampling stations in category VI, manifesting the influence of the $\mathrm{KC}$ on the middle shelf of the southern ECS. These results are consistent with the aforementioned conclusion obtained from the distribution patterns of temperature and salinity in the study area (Section 3.1; Fig. 2a and b). The values of $S_{275-295}$ of the sampling stations in categories I and III were relatively low and varied with a small range (Table 2), suggesting predominance of high molecular weight CDOM at the stations of categories I and III (D'Sa et al., 2014; Guéguen et al., 2014). Values of $S_{275-295}$ in other categories varied with a large range (Table 2), suggesting multiple sources of CDOM in the regions where the sampling stations of these categories located (Astoreca et al., 2009).

\subsubsection{Relationships among CDOM-related parameters}

Fig. 6a shows the relationships of absorption coefficient $\left(a_{280}\right)$ with salinity in different categories. The $a_{280}$ in categories I, II and III showed significant inverse relationships with salinity (category I: $\mathrm{R}^{2}=0.40$, slope $=-0.35, P<0.001$; category II: $\mathrm{R}^{2}=0.40$, slope $=-0.27$, $P<0.001$; category III: $\mathrm{R}^{2}=0.52$, slope $\left.=-0.41, P<0.001\right)$. This relationship suggested a near-conservative mixing of terrestrial CDOM with seawater in the ECS, as observed in other estuarine and coastal systems (Blough and Del Vecchio, 2002; Del Vecchio and Blough, 2004; Hong et al., 2005; Bélanger et al., 2006; Chen et al., 2007, 2015; Granskog et al., 2007, 2012; Astoreca et al., 2009; Matsuoka et al., 2009, 2012; Xie et al., 2012a; Xu et al., 2018). Statistically, the values of slope and intercept from their correlations were similar for the data from the stations in categories I and III, indicating that CDOM properties in these two regions may be optically similar. That is to say, the CDW could reach the middle shelf of the ECS. The data of the sampling stations in categories IV-VI were scattered and no significant correlation was found between $a_{280}$ and salinity (Fig. 6a), suggesting that autochthonous production rather than terrestrial inputs played a major role in influencing the CDOM concentration in the WET and the offshore ECS. Fig. 6b shows that values of $S_{275-295}$ were relatively constant in low salinity waters, while in high salinity waters values of $S_{275-295}$ varied within a relatively large range. Similar results were also observed in other studies (Granskog et al., 2007; Astoreca et al., 2009). This suggested that the mean CDOM molecular weight was relatively uniform in low salinity regions, while in high salinity regions CDOM degraded sufficiently and/or originated from various sources (Brown, 1977; Gao and Zepp, 1998; Stedmon and Markager, 2001). Fig. 6b also shows that the $S_{275-295}$-salinity relationships at sampling stations of categories I and II followed the two-end member conservative mixing behavior, with significant but nonlinear relationships between salinity and $S_{275-295}\left(\mathrm{R}^{2}>0.20, P<0.001\right)$.

CDOM can be produced/released by phytoplankton and its contribution can account for CDOM variability observed in marine environments (Chen et al., 2004b; Astoreca et al., 2009). In the inner shelf of the ECS, significant positive correlations $(P<0.001)$ were observed between Chl $a$ and $a_{280}$ (category I: $\mathrm{R}^{2}=0.42$, category II: $\mathrm{R}^{2}=0.36$; Fig. 6c), manifesting that, besides terrestrial input, phytoplankton may be also an important source for CDOM (Matsuoka et al., 2012; D'Sa et al., 2014). However, previous studies pointed out that the correlations between Chl $a$ and absorption coefficient were likely from a coincidence between high concentrations of Chl $a$ and CDOM, both of them resulted from terrestrial input, rather than an inherent cause-andeffect relationship between Chl $a$ and CDOM (Rochelle-Newall et al., 1999; Rochelle-Newall and Fish, 2002; Chen et al., 2007). In this study, subsurface CDOM maxima usually occurred (Fig. 5a-f), not associated 
Table 2

CDOM properties of the sampling stations in different categories.

\begin{tabular}{|c|c|c|c|c|c|c|c|}
\hline & & I & II & III & IV & $\mathrm{V}$ & VI \\
\hline \multirow[t]{2}{*}{$a_{280}\left(\mathrm{~m}^{-1}\right)$} & Range & $0.50-4.58$ & $0.32-3.74$ & $0.54-2.74$ & $0.26-4.19$ & $0.43-3.65$ & $0.16-3.48$ \\
\hline & Mean \pm SD & $1.78 \pm 1.17$ & $1.14 \pm 0.77$ & $1.30 \pm 0.70$ & $0.89 \pm 0.78$ & $1.28 \pm 1.03$ & $0.61 \pm 0.59$ \\
\hline \multirow[t]{2}{*}{$S_{275-295}\left(\mathrm{~nm}^{-1}\right)$} & Range & $0.018-0.040$ & $0.015-0.065$ & $0.017-0.038$ & $0.014-0.056$ & $0.016-0.044$ & $0.015-0.092$ \\
\hline & Mean \pm SD & $0.027 \pm 0.007$ & $0.033 \pm 0.011$ & $0.028 \pm 0.005$ & $0.034 \pm 0.010$ & $0.031 \pm 0.009$ & $0.034 \pm 0.016$ \\
\hline
\end{tabular}

with low salinity water but probably associated with subsurface Chl $a$ maxima (Fig. 3; Fig. 5a-f). When only the CDOM data in the subsurface maximal layer were plotted against $\mathrm{Chl} a$, a significant positive relationship between them was found $\left(P<0.01, \mathrm{R}^{2}=0.33\right)$. This attested the in situ origin of CDOM from phytoplankton, which has also been observed in other studies (Chen et al., 2004b; D'Sa et al., 2014). For the sampling stations in categories III-VI, however, no significant correlations were found between $a_{280}$ and Chl $a$ (Fig. 6c), suggesting a decoupling of phytoplankton from CDOM. This may indicate that, in offshore regions of the ECS and the WET, other processes, such as photobleaching (Swan et al., 2012), could significantly influence the distribution of CDOM in the water column.

Natural solar radiation could be an important removal mechanism for CDOM (Hulatt et al., 2009; Swan et al., 2012; Xie et al., 2012b). Photochemical degradation can decrease the absorption coefficient and change the CDOM pool to low molecular weight, biologically labile compounds (Mopper and Kieber, 2002; Hulatt et al., 2009; Zhang et al., 2009; D'Sa et al., 2014). In turbid water, the UV-photic zone for photobleaching rarely exceeds $10 \mathrm{~cm}$ (Kowalczuk et al., 2003). Therefore, photobleaching in the nearshore waters of the ECS was inefficient and its effect was masked by water mixing (Fig. 5; Fig. 6a). In the WET, photobleaching effect becomes evident because the turbidity in this region is much lower compared with that of the ECS (Zeng and Hong, 1980). Besides, the less CDOM in the photic zone of the WET (Fig. 4a; Fig. 5e and f) meant that per unit CDOM could receive more photons. These two factors may both contribute to the generally high spectral slopes in the upper water layer $(<300 \mathrm{~m}$ ) of the WET (Fig. 5k and 1).

The $S_{275-295}-a_{280}$ relationship revealed a significant negative correlation $(P<0.001)$ at the sampling stations in different categories when using a nonlinear regression equation as $S_{275-295}=\mathrm{y}_{0}+\mathrm{b} / a_{280}$ (Stedmon and Markager, 2001; D'Sa et al., 2014; Fig. 6d). Although the wavelength range for the determination of spectral slope or absorption coefficient in this study differed from that in Stedmon and Markager (2001) and D'Sa et al. (2014), similar trends were gained. As shown in Fig. $6 \mathrm{~d}$, for the data of the sampling stations in categories I-VI, the $S_{275-295}-a_{280}$ relationship was $S_{275-295}=0.019+0.010 / a_{280}\left(\mathrm{R}^{2}=\right.$ $0.67), \quad S_{275-295}=0.017+0.012 / a_{280} \quad\left(\mathrm{R}^{2}=0.78\right), \quad S_{275-295}$ $=0.022+0.006 / a_{280}\left(\mathrm{R}^{2}=0.38\right), S_{275-295}=0.022+0.007 / a_{280}\left(\mathrm{R}^{2}\right.$ $=0.31), S_{275-295}=0.020+0.008 / a_{280}\left(\mathrm{R}^{2}=0.39\right)$, and $S_{275-295}$ $=0.015+0.008 / a_{280}\left(\mathrm{R}^{2}=0.31\right)$, respectively.

Fig. 4 shows that the river inputs brought high concentrations of CDOM with high molecular weight materials to the coastal regions of the ECS and the decrease in both CDOM molecular weight and concentrations primarily resulted from the dilution of sea water which had
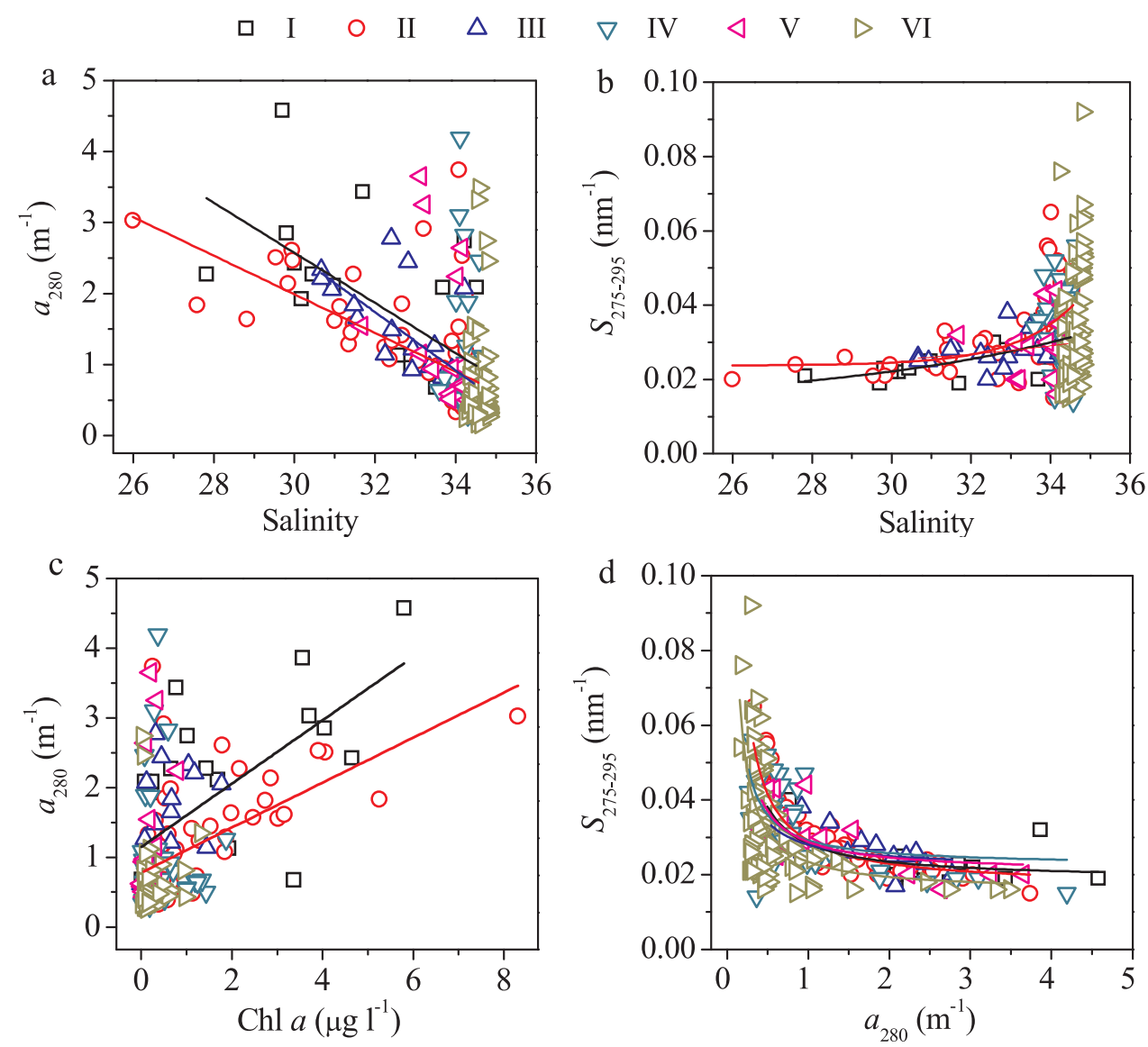

Fig. 6. Relationships between different parameters of the sampling stations in different categories. 
relatively low molecular weight and low concentrations of CDOM. Therefore, a significant negative correlation between $a_{280}$ and $S_{275-295}$ was expected at the stations in categories I-III, where near-conservative mixing of CDOM was found (Fig. 6a). For stations in the rest of the categories, instead of terrestrial inputs, photobleaching and in situ phytoplankton production could be responsible for the negative correlation between $a_{280}$ and $S_{275-295}$, because photobleaching could produce CDOM with low $a_{280}$ values and high $S_{275-295}$ values and phytoplankton production could produce CDOM with high $a_{280}$ values and low $S_{275-295}$ values (Fig. 5; Swan et al., 2012; D'Sa et al., 2014).

\section{Conclusion}

CDOM absorption properties had various characteristics in different regions of the ECS shelf and the WET owing to the impact of different water masses and other factors. In the nearshore waters of the ECS shelf, absorption coefficients $\left(a_{280}\right)$ had generally high values and the spectral slopes $\left(S_{275-295}\right)$ of this area were generally low; vertical distributions of $a_{280}$ and $S_{275-295}$ in this area varied to some extent. In the offshore waters of the ECS shelf, the values of $a_{280}$ were relatively low and $S_{275-295}$ were relatively high; vertical distributions of $a_{280}$ and $S_{275-295}$ in this area were relatively stable. In the WET where the main path of the KC flows through, the values of $a_{280}$ were generally low in both surface and deep waters; the values of $S_{275-295}$ in the upper waters of this region $(<\sim 300 \mathrm{~m})$ were relatively high compared with those in deep waters. Terrestrial input, phytoplankton production, sediment release or photobleaching were supposed to be responsible for the dynamics of CDOM in the study area. The sampling stations in this study were classified into six categories to make a further examination of $\mathrm{CDOM}$ properties and to trace the spatial distribution of water masses. Relationships between the CDOM related parameters supported some of the aforementioned conclusions. In addition, the spatial variation characteristics of CDOM absorption properties also provided a clue that the influence of the CDW could reach the outer shelf of the ECS and the intrusion of the KC could reach the middle shelf of the ECS in the southern part of the study area.

\section{Acknowledgements}

This study was financially supported by the Strategic Priority Research Program of the Chinese Academy of Sciences (XDA11020102, XDA11020702) and the National Natural Science Foundation of ChinaShandong Province Joint Fund for Marine Ecology and Environmental Sciences (U1606404). The assistance of Baoxiao Qu, Changfeng Qu, Qidong Wang and Jiulong Zuo in the sample collection is greatly appreciated. We also give our thanks to the technical assistance from Xuegang Li and Tingyu Wen.

\section{References}

Astoreca, R., Rousseau, V., Lancelot, C., 2009. Coloured dissolved organic matter (CDOM) in Southern North Sea waters: optical characterization and possible origin. Estuar. Coast. Shelf Sci. 85 (4), 633-640.

Bai, Y., Su, R.G., Yan, L.H., Yao, P., Shi, X.Y., Wang, X.L., 2013. Characterization of chromophoric dissolved organic matter (CDOM) in the East China Sea in autumn using excitation-emission matrix (EEM) fluorescence and parallel factor analysis (PARAFAC). Sci. China Chem. 56 (12), 1790-1799.

Bélanger, S., Xie, H., Krotkov, N., Larouche, P., Vincent, W.F., Babin, M., 2006. Photomineralization of terrigenous dissolved organic matter in Arctic coastal waters from 1979 to 2003: interannual variability and implications of climate change. Glob. Biogeochem. Cycles 20, GB4005. http://dx.doi.org/10.1029/2006GB002708.

Bidigare, R.R., Ondrusek, M.E., Brooks, J.M., 1993. Influence of the Orinoco River outflow on distributions of algal pigments in the Caribbean Sea. J. Geophys. Res. 98, 2259-2269.

Blough, N.V., Del Vecchio, R., 2002. Chromophoric DOM in thecoastal environment. In: Hansell, D.A., Carlson, C.A. (Eds.), Biogeochemistry of Marine Dissolved Organic Matter. Academic Press, San Diego, pp. 509-578.

Blough, N.V., Zepp, R.G., 1995. Reactive oxygen species in natural waters. In: Foote, C.S., Valentine, J.S. (Eds.), Active Oxygen in Chemistry. Chapman and Hall, pp. 280-333.

Boss, E., Pegau, W.S., Zaneveld, J.R.V., Barnard, A.H., 2001. Spatial and temporal variability of absorption by dissolved material at a continental shelf. J. Geophys. Res. 106, 9499-9507.

Brown, M., 1977. Transmission spectroscopy examinations of natural waters: C.

Ultraviolet spectral characteristics of the transition from terrestrial humus to marine yellow substance. Estuar. Coast. Mar. Sci. 5 (3), 309-317.

Carder, K.L., Steward, R.G., Harvey, G.R., Ortner, P.B., 1989. Marine humic and fulvic acids: their effects on remote sensing of ocean chlorophyll. Limnol. Oceanogr. 34, 68-81.

Chen, C.T.A., 1996. The Kuroshio intermediate water is the major source of nutrients on the East China Sea continental shelf. Oceanol. Acta 19, 523-527.

Chen, C.T.A., Ruo, R., Pai, S.C., Liu, C.T., Wong, G.T.F., 1995. Exchange of water masses between the East China Sea and the Kuroshio off northeastern Taiwan. Cont. Shelf Res. 15 (1), 19-39.

Chen, C.T.A., Wang, S.L., 2006. A salinity front in the southern East China Sea separating the Chinese coastal and Taiwan Strait waters from Kuroshio waters. Cont. Shelf Res. 26, 1636-1653.

Chen, Y.L.L., Chen, H.Y., Lin, Y.H., 2003. Distribution and downward flux of Trichodesmium in the South China Sea as influenced by the transport from the Kuroshio Current. Mar. Ecol. Prog. Ser. 259, 47-57.

Chen, Z.Q., Doering, P.H., Ashton, M., Orlando, B.A., 2015. Mixing behavior of colored dissolved organic matter and its potential ecological implication in the Caloosahatchee River Estuary, Florida. Estuaries Coasts 38 (5), 1706-1718.

Chen, Z.Q., Hu, C.M., Conmy, R.N., Muller-Karger, F., Swarzenski, P., 2007. Colored dissolved organic matter in Tampa Bay, Florida. Mar. Chem. 104, 98-109.

Chen, Z.Q., Li, Y., Pan, J.M., 2004a. Distributions of colored dissolved organic matter and dissolved organic carbon in the Pearl River Estuary, China. Cont. Shelf Res. 24 (16), 1845-1856.

Chen, R.F., Bissett, P., Coble, P., Conmy, R., Gardner, G.B., Moran, M.A., Wang, X.C., Wells, M.L., Whelan, P., Zepp, R.G., 2004. Chromophoric dissolved organic matter (CDOM) source characterization in the Louisiana Bight. Mar. Chem. 89 (1-4), 257-272.

Coble, P.G., Del Castillo, C.E., Avril, B., 1998. Distribution and optical properties of CDOM in the Arabian Sea during the 1995 Southwest monsoon. Deep-Sea Res. II 45, 2195-2223.

Dainard, P.G., Guéguen, C., 2013. Distribution of PARAFAC modeled CDOM components in the North Pacific Ocean, Bering, Chukchi and Beaufort Seas. Mar. Chem. 157, 216-223.

Del Castillo, C.E., Miller, R.L., 2011. Horizontal and vertical distributions of colored dissolved organic matter during the Southern Ocean Gas Exchange Experiment. J. Geophys. Res. 116, C00F07. http://dx.doi.org/10.1029/2010JC006781.

Del Vecchio, R., Blough, N.V., 2004. Spatial and seasonal distribution of chromophoric dissolved organic matter and dissolved organic carbon in the Middle Atlantic Bight. Mar. Chem. 89, 169-187.

Del Vecchio, R., Subramaniam, A., 2004. Influence of the Amazon River on the surface optical properties of the western tropical North Atlantic Ocean. J. Geophys. Res. 109, C11001. http://dx.doi.org/10.1029/2004JC002503.

D’Sa, E.J., Goes, J.I., Gomes, H., Mouw, C., 2014. Absorption and fluorescence properties of chromophoric dissolved organic matter of the eastern Bering Sea in the summer with special reference to the influence of a cold pool. Biogeosciences 11 (12), 3225-3244.

Fang, T.H., Chen, J.L., Huh, C.A., 2007. Sedimentary phosphorus species and sedimentation flux in the East China Sea. Cont. Shelf Res. 27 (10-11), 1465-1476.

Fichot, C.G., Benner, R., 2011. A novel method to estimate DOC concentrations from CDOM absorption coefficients in coastal waters. Geophys. Res. Lett. 38, L03610. http://dx.doi.org/10.1029/2010GL046152.

Fichot, C.G., Kaiser, K., Hooker, S.B., Amon, R.M.W., Babin, M., Bélanger, S., Walker, S.A., R. Benner, R., 2013. Pan-Arctic distributions of continental runoff in the Arctic Ocean. Sci. Rep. 3, 1053. http://dx.doi.org/10.1038/srep01053.

Gao, H.Z., Zepp, R.G., 1998. Factors influencing photoreactions of dissolved organic matter in a coastal river of the southeastern United States. Environ. Sci. Technol. 32, 2940-2946.

Gao, L., Fan, D.D., Li, D.J., Cai, J.G., 2010. Fluorescence characteristics of chromophoric dissolved organic matter in shallow water along the Zhejiang coasts, southeast China. Mar. Environ. Res. 69, 187-197.

Gao, X.L., Chen, C.T.A., 2012. Heavy metal pollution status in surface sediments of the coastal Bohai Bay. Water Res. 46 (6), 1901-1911.

Gao, X.L., Zhou, F.X., Chen, C.T.A., 2015a. Trace metals in the suspended particulate matter of the Yellow River (Huanghe) Estuary: concentrations, potential mobility, contamination assessment and the fluxes into the Bohai Sea. Cont. Shelf Res. 104, 25-36.

Gao, X.L., Zhuang, W., Chen, C.T.A., Zhang, Y., 2015b. Sediment quality of the SW coastal Laizhou Bay, Bohai Sea, China: a comprehensive assessment based on the analysis of heavy metals. PLoS One 10 (3), e0122190. http://dx.doi.org/10.1371/journal.pone. 0122190 .

Gardner, G.B., Chen, R.F., Berry, A., 2005. High-resolution measurements of chromophoric dissolved organic matter (CDOM) in the Neponset River estuary, Boston Harbor, MA. Mar. Chem. 96, 137-154.

Gong, G.C., 2004. Absorption coefficients of colored dissolved organic matter in the surface waters of the East China Sea. Terr., Atmos. Ocean. Sci. 15, 75-87.

Gong, G.C., Yang, W.J., Chang, J., 1995. In vivo fluorescence-derived chlorophyll a concentrations in the southern East China Sea. Acta Oceanogr. Taiwan. 34, 73-85.

Gong, G.C., Yang, W.R., Wen, Y.H., 1993. Correlation of chlorophyll $a$ concentration and Sea tech fluorometer fluorescence in seawater. Acta Oceanogr. Taiwan. 31, 117-126.

Granskog, M.A., Macdonald, R.W., Mundy, C.J., Barber, D.G., 2007. Distribution, characteristics and potential impacts of chromophoric dissolved organic matter (CDOM) in Hudson Strait and Hudson Bay, Canada. Cont. Shelf Res. 27 (15), 2032-2050. 
Granskog, M.A., Stedmon, C.A., Dodd, P.A., Amon, R.M.W., Pavlov, A.K., de Steur, L., Hansen, E., 2012. Characteristics of colored dissolved organic matter (CDOM) in the Arctic outflow in the Fram Strait: assessing the changes and fate of terrigenous CDOM in the Arctic Ocean. J. Geophys. Res. 117, C12021. http://dx.doi.org/10.1029/ 2012JC008075.

Green, S.A., Blough, N.V., 1994. Optical absorption and fluorescence properties of chromophoric dissolved organic matter in natural waters. Limnol. Oceanogr. 39, 1903-1916.

Guéguen, C., Cuss, C.W., Cassels, C.J., Carmack, E.C., 2014. Absorption and fluorescence of dissolved organic matter in the waters of the Canadian Arctic Archipelago, Baffin Bay, and the Labrador Sea. J. Geophys. Res. 119 (3), 2034-2047.

Guéguen, C., Guo, L., Tannaka, N., 2005. Distributions and characteristics of colored dissolved organic matter in the Western Arctic Ocean. Cont. Shelf Res. 25, 1195-1207.

Guéguen, C., Kowalcyuk, P., 2013. In: Belkin, I.M. (Ed.), Colored dIssolved Organic Matter in Frontal Zones. Chemical Oceanography of Frontal Zones. http://dx.doi.org/ $10.1007 / 6982013244$.

Hancke, K., Hovland, E.K., Volent, Z., Pettersen, R., Johnsen, G., Moline, M., Sakshaug, E., 2014. Optical properties of CDOM across the Polar Front in the Barents Sea: origin, distribution and significance. J. Mar. Syst. 130, 219-227.

Helms, J.R., Stubbins, A., Ritchie, J.D., Minor, E.C., Kieber, D.J., Mopper, K., 2008. Absorption spectral slopes and slope ratios as indicators of molecular weight, source, and photobleaching of chromophoric dissolved organic matter. Limnol. Oceanogr. 53, 955-969.

Hong, H.S., Wu, J.Y., Shang, S.L., Hu, C.M., 2005. Absorption and fluorescence of chromophoric dissolved organic matter in the Pearl River Estuary, South China. Mar. Chem. 97 (1-2), 78-89.

Hu, C.M., Muller-Karger, F.E., Zepp, R.G., 2002. Absorbance, absorption coefficient, and apparent quantum yield: a comment on common ambiguity in the use of these optical concepts. Limnol. Oceanogr. 47, 1261-1267.

Hulatt, C.J., Thomas, D.N., Bowers, D.G., Norman, L., Zhang, C., 2009. Exudation and decomposition of chromophoric dissolved organic matter (CDOM) from some temperate macroalgae. Estuar., Coast. Shelf Sci. 84 (1), 147-153.

Kowalczuk, P., Cooper, W.J., Whitehead, R.F., Durako, M.J., Sheldon, W., 2003. Characterization of CDOM in an organic-rich river and surrounding coastal ocean in the South Atlantic Bight. Aquat. Sci. 65 (4), 384-401.

Laurion, I., Ventura, M., Catalan, J., Psenner, R., Sommaruga, R., 2000. Attenuation of ultraviolet radiation in mountain lakes: factors controlling the among- and withinlake variability. Limnol. Oceanogr. 45, 1274-1288.

Lei, H., Pan, D.L., Bai, Y., Tao, B.Y., Sun, J., Zhang, L., Zhang, X., 2012. The proportions and variations of the light absorption coefficients of major ocean color components in the East China Sea. Acta Oceanol. Sin. 31 (2), 45-61.

Li, G.J., Liu, J., Ma, Y.L., Zhao, R.H., Hu, S.Z., Li, Y.J., Wei, H., Xie, H.X., 2014 Distribution and spectral characteristics of chromophoric dissolved organic matter in a coastal bay in northern China. J. Environ. Sci. 26 (8), 1585-1595,

Lin, H., Cai, Y.H., Sun, X.W., Chen, G.X., Huang, B.Q., Chen, H., Chen, M., 2016. Sources and mixing behavior of chromophoric dissolved organic matter in the Taiwan Strait. Mar. Chem. 187, 43-56.

Lin, H., Guo, W.D., Hu, M.H., Lin, C., Ji, W.D., 2012. Spatial and temporal variability of colored dissolved organic matter absorption properties in the Taiwan Strait. Acta Oceanol. Sin. 31 (5), 98-106.

Ling, S., 1999. The coastal landscape of eastern Taiwan. Technol. Ind. Across Straits 3 , 39-40 (in Chinese).

Liu, J.P., Liu, C.S., Xu, K.H., Milliman, J.D., Chiu, J.K., Kao, S.J., Lin, S.W., 2008. Flux and fate of small mountainous rivers derived sediments into the Taiwan Strait. Mar. Geol. 256, 65-76.

Liu, K.K., Yan, W.J., Lee, H.J., Chao, S.Y., Gong, G.C., Yeh, T.Y., 2015. Impacts of increasing dissolved inorganic nitrogen discharged from Changiiang on primary production and seafloor oxygen demand in the East China Sea from 1970 to 2002. J. Mar. Syst. 141, 200-217.

Liu, X.H., Zhang, Y.L., Shi, K., Zhu, G.W., Xu, H., Zhu, M.Y., 2014a. Absorption and fluorescence properties of chromophoric dissolved organic matter: implications for the monitoring of water quality in a large subtropical reservoir. Environ. Sci. Pollut. Res. 21 (24), 14078-14090.

Liu, Y.Y., Shen, F., Li, X.Z., 2014b. Light absorption properties of colored dissolved organic matter (CDOM) in adjacent waters of the Changjiang Estuary during a flood season: implication for DOC estimation. In: Proceedings of Society of Photo-Optical Instrumentation Engineers 9261, Ocean Remote Sensing and Monitoring from Space, 92610k, doi:10.1117/12.2069245.

Matsuoka, A., Bricaud, A., Benner, R., Para, J., Sempéré, R., Prieur, L., Bélanger, S., Babin, M., 2012. Tracing the transport of colored dissolved organic matter in water masses of the Southern Beaufort Sea: relationship with hydrographic characteristics. Biogeosciences 9 (3), 925-940.

Matsuoka, A., Larouche, P., Poulin, M., Vincent, W., Hattori, H., 2009. Phytoplankton community adaptation to changing light levels in the southern Beaufort Sea, Canadian Arctic. Estuar., Coast. Shelf Sci. 82, 537-546.

Matsuoka, A., Ortega-Retuerta, E., Bricaud, A., Arrigo, K.R., Marcel, B., 2015. Characteristics of colored dissolved organic matter (CDOM) in the Western Arctic Ocean: relationships with microbial activities. Deep-Sea Res. II 118, 44-52.

Miller, W.L., Zepp, R.G., 1995. Photochemical production of dissolved inorganic carbon from terrestrial organic matter: significance to the oceanic organic carbon cycle. Geophys. Res. Lett. 22, 417-420.

Mopper, K., Kieber, D.J., 2002. Photochemistry and the cycling of carbon, sulfur, nitrogen, and phosphorus. In: Carlson, C., Hansell, D. (Eds.), Biogeochemistry of Marine Dissolved Organic Matter. Academic Press, pp. 455-508.

Naik, H., Chen, C.T.A., 2008. Biogeochemical cycling in the Taiwan Strait. Estuar., Coast.
Shelf Sci. 78 (4), 603-612.

Nelson, N.B., Carlson, C.A., Steinberg, D.K., 2004. Production of chromophoric dissolved organic matter by Sargasso Sea microbes. Mar. Chem. 89, 273-287.

Nelson, N.B., Siegel, D.A., Michaels, A.F., 1998. Seasonal dynamics of colored dissolved organic material in the Sargasso Sea. Deep-Sea Res. I 45, 931-957.

Organelli, E., Bricaud, A., Antoine, D., Matsuoka, A., 2014. Seasonal dynamics of light absorption by chromophoric dissolved organic matter (CDOM) in the NW Mediterranean Sea (BOUSSOLE site). Deep-Sea Res. I 91, 72-85.

Pan, K., Wang, W.X., 2012. Trace metal contamination in estuarine and coastal environments in China. Sci. Total Environ. 421, 3-16.

Para, J., Charrière, B., Matsuoka, A., Miller, W.L., Rontani, J.F., Sempéré, R., 2013. UV/ PAR radiation and DOM properties in surface coastal waters of the Canadian shelf of the Beaufort Sea during summer 2009. Biogeosciences 10 (4), 2761-2774.

Rochelle-Newall, E.J., Fish, T.R., 2002. Chromophoric dissolved organic matter and dissolved organic carbon in Chesapeake Bay. Mar. Chem. 77, 23-34.

Rochelle-Newall, E.J., Fish, T.R., Fan, C., Glibert, P.M., 1999. Dynamics of chromophoric dissolved organic matter and dissolved organic carbon in experimental mesocosms. Int. J. Remote Sens. 20, 627-641.

Sasaki, H., Gomi, Y., Asai, T., Shibata, M., Kiyomoto, Y., Okamura, K., Nishiuchi, K. Hasegawa, T., Yamada, H., 2014. Unique dispersal of the changjiang-diluted water Plume in the East China Sea revealed from satellite monitoring of Colored Dissolved Organic Matter (CDOM). Terr. Atmos. Ocean. Sci. 25 (2), 279-287.

Stedmon, C.A., Amon, R.M.W., Rinehart, A.J., Walker, S.A., 2011. The supply and characteristics of colored dissolved organic matter (CDOM) in the Arctic Ocean: pan Arctic trends and differences. Mar. Chem. 124, 108-118.

Stedmon, C.A., Markager, S., 2001. The optics of chromophoric dissolved organic matter $(\mathrm{CDOM})$ in the Greenland Sea: an algorithm for differentiation between marine and terrestrially derived organic matter. Limnol. Oceanogr. 46, 2087-2093.

Stedmon, C.A., Osburn, C.L., Kragh, T., 2010. Tracing water mass mixing in the BalticNorth Sea transition zone using the optical properties of coloured dissolved organic matter. Estuar., Coast. Shelf Sci. 87, 156-162.

Strickland, J.D.H., Parsons, T.R., 1972. A Practical Handbook of Seawater Analysis. Fisheries Research Board of Canada, Ottawa, Canada, pp. 310.

Su, R.G., Bai, Y., Zhang, C.S., Shi, X.Y., 2015. The assessment of the spatial and seasonal variability of chromophoric dissolved organic matter in the Southern Yellow Sea and the East China Sea. Mar. Pollut. Bull. 100, 523-533.

Sun, Q.Y., Wang, C., Wang, P.F., Hou, J., Ao, Y.H., 2014. Absorption and fluorescence characteristics of chromophoric dissolved organic matter in the Yangtze Estuary. Environ. Sci. Pollut. Res. 21 (5), 3460-3473.

Swan, C.M., Nelson, N.B., Siegel, D.A., Kostadinov, T.S., 2012. The effect of surface irradiance on the absorption spectrum of chromophoric dissolved organic matter in the global ocean. Deep-Sea Res. I 63, 52-64.

Tranvik, L.J., Downing, J.A., Cotner, J.B., Loiselle, S.A., Striegl, R.G., Ballatore, T.J., Dillon, P., Finlay, K., Fortino, K., Knoll, L.B., Kortelainen, P.L., Kutser, T., Larsen, S., Laurion, I., Leech, D.M., Leigh McCallister, S.L., McKnight, D.M., Melack, J.M., Overholt, E., Porter, J.A., Prairie, Y., Renwick, W.H., Roland, F., Sherman, B.S. Schindler, D.W., Sobek, S., Tremblay, A., Vanni, M.J., Verschoor, A.M., von Wachenfeldt, E., Weyhenmeyer, G.A., 2009. Lakes and reservoirs as regulators of carbon cycling and climate. Limnol. Oceanogr. 54, 2298-2314.

Vodacek, A., Blough, N.V., DeGrandpre, M.D., Peltzer, E.T., Nelson, R.K., 1997. Seasonal variation of CDOM and DOC in the Middle Atlantic Bight: terrestrial inputs and photooxidation. Limnol. Oceanogr. 42 (4), 674-686.

Wang, Y., Zhang, D., Shen, Z.Y., Chen, J., Feng, C.H., 2014. Characterization and special distribution variability of chromophoric dissolved organic matter (CDOM) in the Yangtze Estuary. Chemosphere 95, 353-362.

Xie, H.X., Aubry, C., Bélanger, S., Song, G.S., 2012a. The dynamics of absorption coefficients of CDOM and particles in the St. Lawrence estuarine system: biogeochemica and physical implications. Mar. Chem. 128-129, 44-56.

Xie, H.X., Bélanger, S., Song, G., Benner, R., Taalba, A., Blais, M., Tremblay, J.É., Babin, M., 2012b. Photoproduction of ammonium in the southeastern Beaufort Sea and its biogeochemical implications. Biogeosciences 9 (8), 3047-3061.

Xing, Q.G., Tosi, L., Braga, F., Gao, X.L., Gao, M., 2015. Interpreting the progressive eutrophication behind the world's largest macroalgal blooms with water quality and ocean color data. Nat. Hazards 78 (1), 7-21.

Xu, H.C., Guo, L.D., 2017. Molecular size-dependent abundance and composition of dissolved organic matter in river, lake and sea waters. Water Res. 117, 115-126.

Xu, H.C., Houghton, E.M., Houghton, C.J., Guo, L.D., 2018. Variations in size and composition of colloidal organic matter in a negative freshwater estuary. Sci. Total Environ. 615, 931-941.

Yang, L.Y., 2012. Dynamics of Dissolved Organic Matter in the River-estuary Systems and Influencing Factors. Doctoral Dissertation of Xiamen University, Xiamen, China (in Chinese with English abstract).

Yang, L.Y., Chen, C.T.A., Lui, H.K., Zhuang, W.E., Wang, B.J., 2016. Effects of microbial transformation on dissolved organic matter in the east Taiwan Strait and implications for carbon and nutrient cycling. Estuar., Coast. Shelf Sci. 180, 59-68.

Yang, L.Y., Hur, J., 2014. Critical evaluation of spectroscopic indices for organic matte source tracing via end member mixing analysis based on two contrasting sources. Water Res. 59, 80-89.

Yu, X.L., Shen, F., Liu, Y.Y., 2016. Light absorption properties of CDOM in the Changjiang (Yangtze) estuarine and coastal waters: an alternative approach for DOC estimation. Estuar., Coast. Shelf Sci. 181, 302-311.

Yu, Y., Song, J.M., Li, X.G., Yuan, H.M., Li, N., Duan, L.Q., 2013. Environmental significance of biogenic elements in surface sediments of the Changjiang Estuary and its adjacent areas. J. Environ. Sci. 25 (11), 2185-2195.

Zeng, G., Hong, Q.M., 1980. The mean annual hydrological regimes over years in the Taiwan Strait and the adjacent sea area. Mar. Sci. Technol. Inf. 7, 1-15 (in Chinese). 
Zhang, M.W., Tang, J.W., Dong, Q., Song, Q.T., Ding, J., 2010b. Retrieval of total suspended matter concentration in the Yellow and East China Seas from MODIS imagery. Remote Sens. Environ. 114, 392-403.

Zhang, Y., Xie, H., 2015. Photomineralization and photomethanification of dissolved organic matter in Saguenay River surface water. Biogeosciences 12, 6823-6836.

Zhang, Y.L., Liu, M.L., Qin, B.Q., Feng, S., 2009. Photochemical degradation of chromophoric-dissolved organic matter exposed to simulated UV-B and natural solar radiation. Hydrobiologia 627 (1), 159-168.

Zhang, Y.L., Zhang, E.L., Yin, Y., van Dijk, M.A., Feng, L.Q., Shi, Z.Q., Liu, M.L., Qin, B.Q. 2010a. Characteristics and sources of chromophoric dissolved organic matter in lakes of the Yungui Plateau, China, differing in trophic state and altitude. Limnol.
Oceanogr. 55 (6), 2645-2659.

Zhou, M.J., Shen, Z.L., Yu, R.C., 2008. Responses of a coastal phytoplankton community to increased nutrient input from the Changjiang (Yangtze) River. Cont. Shelf Res. 28 (12), 1483-1489.

Zhou, Y.X., 1994. The marine environment of Taiwan and its conservation work. Mar. Inf. 12, 16-18 (in Chinese).

Zhu, C., Wang, Z.H., Xue, B., Yu, P.S., Pan, J.M., Wagner, T., Pancost, R.D., 2011.

Characterizing the depositional settings for sedimentary organic matter distributions in the Lower Yangtze River-East China Sea Shelf System. Estuar., Coast. Shelf Sci. 93 (3), 182-191. 